\title{
Xレーフイルムの常識
}

小西六寫真工業株式會社東京營業所Xレ一課

森祐 一

\section{Common Sense of X-Ray Film}

\author{
Yuichi Mori
}

ToKyo Office, Konishiroku Shashin-Kogyo K. K.

$\mathrm{X}$ メーフイルムは御存知の通りレントゲン写真を撮 影する為のフイルムで，その構造や性能も普通写真に 使われるフイルムと違つて色々と変つた点があります ので，このフイルムを御取扱い願う場合の御参考迄に 三三申述へさせて頂きます。

一般に直接撮影用と称している, カビネから半切迄 のシートフイルム（増感紙の間に㨉んで取枠に入れて 使用するすの）は，さくらXレーフイルムでは厚ざ 17 20/100 m/m 程度のセルロイドベース耐面にX線とX 楾に依り発する増感紙の煏光に感ずる感光乳剤 (レギ ニラー乳凧）を塗布したるので，両面に黒当紙を当て 防㬎の為に金属䇴に包几で外箱に入れてあります。

又間接撮影用フイルムはブローニーフイルム $(\mathrm{J}-$ $120,6 \times 6 \mathrm{~cm}$ サイズ 12 枚撮) と $35 \mathrm{~mm}$ フイルム (JX $-135,24 \times 24 m / m$ サイズ 50 枚撮) の二種類出ておりま 寸か，之は両方共 X線に依る螢光板の溃光映像を撮影 する為に直接用より長波長光に感光する様な感光乳風 (オルソパン乳凧)を、さくらXレーフイルムの場合, ブローニーは 8 / $/ 100 \mathrm{~m} /, 35 \mathrm{~mm}$ は $11 \sim / 100 \mathrm{~m} / \mathrm{m}$ の厚 さのセルロイドベースの片面に塰布したもので，包装 は一般写真用と同様にプローニーは金属䇴で包んだす のを外箱に入れ， $35 \mathrm{~mm}$ は 1 本宛黒紙で包んだものを 3 本毎に金属罐に入れてあります.

普通写真用フイルムは特殊のすのを除いて太陽光下 に肉眼で認められる沉ゆる色に均等に感光する様に乳 阂中に感光色素を入れたり，又出来上つた画像を大倍 率に抾大してる差支学ない様に銀粒子を細かくしたり してありますが，その反面撮影には主に強烈な太陽光 線を使用する関保上，感光度の方は無闇に速くしなく ても充分間に合います。

Xレーフイルムの方は微弱な X線若しくは䝁光に感 光して良好な画像を得る為に最高の感度と適当なコン トラストを要求されますので，感光材料製造の側に於 ても高度の技術之細心の注意が必要であり，それに伴 つて保存その他御取扱いの上にる他の感光材料に比較
して尙一層御往意願わねばならない点が出て参りま す.

以下Xレーフイルム御取扱いに際して事故発生の原 因となる条件を列記して見ますと

\section{(一) 高温度}

高温の場所に Xレーフイルムを置いたり致しますと フイルムの変質が早められ，カブリその他種くの事故 の原因となります。

\section{(二) 高湿度}

この場合る高温の時と同様にカブリを発生したりそ の他感度低下の原因ともなり易いすのです。

\section{(三) 加 E}

フイルムに強い压力が加つた時, 例えば, フイルム を多数重ねて平に積んだり又は上に重量物を㯰いたり しますと隇感その他の事故を発生する事があり，又こ の際前記の高温高湿状態にある場合は更に事故を促進 する因になります。

\section{（四）㝝 撚}

Xレーフイルムは御存知の如くセルロイドのベース 面に感光乳㓮を峌布したものですがこの感光乳剤はゼ ラチンとハロゲン化銀等から出来ている為非常に摩擦 に対して弱く，撮影若しくは現像操作の時值接膜面を 摩摖すれば勿論，未開封のるのでも甚しい動摇を与兄 ればスリキズやスタテイックと称する事故（電光状や 樹枝状の 模様が 現像後現れる現象）の原因となりま 于.

\section{（五） 不注意感光}

フイルムを明所で開けてしまつたりその他可視光線 (肉眼で諗められる光線) で感光させたるのは別とし て，X線やラデウム放射線，又は最近ラデウムに代つ て使用されて来たフイントープの放射線等に侤つて不 用意に感光させてしまつたものは，フイルム不良に基 ずくカブリと誤認し易いすのです.

さくらXレーフイルム直接用には之を識別する鋏の 桜型文ニうが外箱に入れてありますが之は後述します 
この他にも有りますが以上列挙致しました点が Xレ ーフイルム事故原因の大半を占めていると申しても過 言ではないと思います。

そこでこのフイルムの御取扱いに際して事故を防止 寸るには，以上の点に御留意下されば宜しい訳で，保 存に最す理想的な状態としてはフイルムが少量の場合 は密閉した容器の中に入れ下部にシリカゲルや㙁化カ ルシウム，生石灰等の乾燥剤を入れて冷䀧所に置けば 良いのですが，実際はこの様な事は数量が多い時には 不可能な事わあり実用的には出来る限り低温度, 低湿 度の所に置く様にして頂ければ良いと思います。

又その際成可く平に積重ねる様な事はせず，フイル

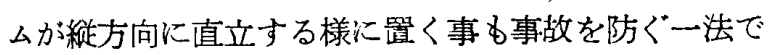
す.

更に運搬汇当つてフイルムを投出したりその他激し い衝撃を与える事も注意して頂きたいものです.

さて最後に X線其の他の不可視光線に依る感光事故 に就て申上げますが，之は知らない中に感光している 事加多い関係上往々にしてフイルム製造上の事故や，
高温, 高湿等に依るカブリの発生と誤認しがちで,こ の点を判然と区別し又御使用者がその様な有害放射線 に知らずに浸される様な危険を警告する意味で直接撮 影用のさくらXレーフイルムの外箱両面には薄い銛の 桜型マークが入れてあります。

レントゲン撮影や透視をしている時レントゲン室に フイルムを持つて入つたり,フイルムの貯蔵してある 室の近くにラヂウムやアイソトーブが置いてあつたり して外箱の上からこの様な放射線に感光しますと，現 像後のフイルムの真中に桜のマークが白拢きになつて 現れて参ります。

有害放射線を受けているかどうかという事はフイル ムを現像して見なければ分らない事ですあり．現在で も時々さくらマークの事を御存知ない向からこれの出 現に対して御比言を頂きますので，この事故も案外多 いのではないかと思い附記した次第です。

以上非常に概略の記述になりましたが Xレーフイル 么御取扱上御参考になれば幸です。

\section{常 識 講 座}

（問）電解研磨とは何ですか。

（答）金属を燐酸や硫酸などの溶液に浸して，それ を陽極として直流を短時間に流し電気的にその表面を 滑かにして光沢を与充る方法であつて, 機峨的に磨く のではない，原理的には電気メッキの逆を行うのので 機械的に磨く方法に較べて遥かに美しく滑らかな表面 処理が極めて短時間にできる. 1931 年フランスで案出 され：この十年の間にアメリカでかなりよく発達し日 本でも最近いるいろな方面に応用されはじめた。

(問) プラスチックスを御説明下さい.

（答）一般に温度や圧力を加兄て自由な形に作れる もの, 即ち可望性物質をい5. 天然樹脂, 合成樹脂, セルロイド, 天然ゴム, 人造ゴム, フスファルトなど いずれるプラスチックスだが，最近では合成樹脂わけ てもヴィニル系の樹脂がプラスチックスの 主流をなし ている. プラスチックスは大別すると熱を加えると硬 化して再び元に戻らない熱硬化性プラスチックス（べ 一クライトなど）と，加熱すると軟化し冷却すると固 くなる熱可塑性プラスチックス（ヴィニル 系樹脂やセ ルロイドなど）とに分けられる．分子量が大きく，所 謂高分子化合物に属する.

(問) 次に合成樹脂とは?

（答）シェラックやコハクなとの天然樹脂に対して 人工的に合成した樹脂を広く合成樹脂とい5が，余り にす種類が多く，用途も多方面にわたるので，簡単に その概念をいい現すのは難しい，合成樹脂はブラスチ ックスの代表的なるのだが，同義語ではない。合成樹 脂を便宣的に大別すると第一が石炭酸系樹脂で歴史も
古く拓椀, 電気のソケット, 電話器などに使われるべ 一クライト（商品名）がその代諘. 最近になつて無色 透明なるのもできるよ5になつた。第二は尿素采樹脂

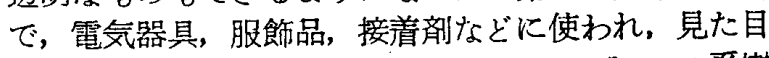
も美しい、第三は新興プラスチックスのヴィニル系樹 脂で，これが更に醋酸ヴィニル，塩化ヴィニル，アクリ ル，スチロールなど原料の種類によつて区別される. 街の風船バッブルスやチューインガムの基体は醌酸ヴ イニル系. レインコートやハンドバッグ, ヴィニヨン, サランなどの人造絩維は塩化ヴィニル系. 飛行機や自 動車の風防ガラス，シガレットケース，櫛などはアク リル秃といつた具合だが，この他ポリアミドと呼ばれ るナイロン, アミランのよ５な人造繊維す合成樹脂の 一族である. 合成樹脂は何れむ分子量の小さい物質を 重合させてでさた高分子化合物である. 重合の際，水 その他の物質の失われる変化を縮重合（ベークライト など) という.

(問) ナイロンを略説して下さい。

（答）天然の絹と非常に似た構造を持つ合成緎維. 1935 年米国デェポン会社のW・H・カローザースの発 明したすの.弾性があり文夫で耐久力が絹の二・三倍 ああるため, アメリカの婦人の靴下は大部分ナイロン となりつつある。絹，人䅌などと混織されることもあ り, 各種のブラッシ, 釣䒺, 魚網などにす使われる。 化学的にはポリアミドという合成樹脂の一種で,ドイ ッの $\mathrm{I} ・ \mathrm{G}$ 会社のペルロン, 日本の東洋レーヨン会社 のアミランなども大体類似のるの. 俗にナイロンのハ ンドバックとい5のは実は塩化ヴィニルなとであるこ とが多い. 